ICAMS $2016-6^{\text {th }}$ International Conference on Advanced Materials and Systems

\title{
APPLICATIONS OF LIFE CYCLE ASSESSMENT TO LEATHER INDUSTRY - AN OVERVIEW AND A CASE STUDY
}

\author{
SERGIU-ADRIAN GU $\breve{A}$, LUMINI A ALBU, GHEORGHE BOSTACA \\ INCDTP - Division Leather and Footwear Research Institute (ICPI), 93, Ion Minulescu str., \\ Bucharest, Romania,email: icpi@icpi.ro
}

\begin{abstract}
Global temperature increase is attributed to industrial pollution, rising number of automotive vehicles, deforestation, growing use of chemical fertilizers etc. In the future the potential increase of temperature even by $2^{\circ} \mathrm{C}$ could have a dramatic impact on life on Earth. Leather industry activities use hazardous chemical substances that generate an important quantity of $\mathrm{CO}_{2}$ with a direct impact on global warming. The first part of the paper presents the LCA concept, methodologies and some relevant LCA studies for leather industry as a means to identify the main environmental impact "contributors". In the second part the paper presents a gate-to-gate Life Cycle Assessment (LCA) case study for processing a leather assortment. The analyzed assortment is natural full grain, bovine leather, thickness $1.4-1.6 \mathrm{~mm}$, domestic raw material, manufactured by a Romanian tannery in one year period. The study was conducted using GaBi ts - Life Cycle Assessment software, version 7.2.2.28, 2016.
\end{abstract}

Keywords: life-cycle assessment, leather processing, carbon footprint

\section{INTRODUCTION}

There is a direct correlation between the increase of anthropogenic green house gases [Methane $\left(\mathrm{CH}_{4}\right)$, Nitrogen Oxide $\left(\mathrm{N}_{2} \mathrm{O}\right)$ etc.], especially of Carbon dioxide $\left(\mathrm{CO}_{2}\right)$, and the increase of global average temperature - global warming. These gases warm the Earth by absorbing energy and slowing the rate at which the energy escapes to space. The $\mathrm{CO}_{2}$ concentration has constantly increased from $357 \mathrm{ppmv}$ (parts per million by volume) in 1992 to 389 ppmv in 2011 (Brugnoli and Král, 2012). At the end of 2015 The United Nations Climate Change Conference was held in Paris, France, which debated the issued of global warming. The participating 195 countries agreed, by consensus, on the reduction of climate change by reduction of greenhouse gases and keeping the global temperature increase below $2{ }^{\circ} \mathrm{C}$. But even that limit will have a dramatic effect on the world's climate (Wikipedia, 2016).

Leather industry which transforms raw skins and hides of animals, a by-product of meat industry, into a stable material called leather, by using, among other materials, hazardous chemical substances, is in the top of world pollutants. Hence leather processing activities have a direct impact on global warming by $\mathrm{CO}_{2}$ emissions. The paper will present a study that aims to reveal the environmental impact of leather processing activities in the form of $\mathrm{CO}_{2}$ emissions. Impact of different products, processes on the environment is determined by using Life Cycle Assessment (LCA) approach. LCA is a technique of evaluation of the actions exerted on the environment by all associated production phases, which transform raw skins/hides into finished leather. An LCA study proposes an "environmental picture" of manufacturing processes offering valuable information regarding inputs and outputs of the materials used, energy consumption, carbon footprint. 


\section{LIFE CYCLE ASSESSMENT IN LEATHER INDUSTRY}

This section presents some relevant LCA studies conducted until 2016 for the leather sector. Special attention was given to the LCA studies for the Italian and Spanish leather sector as these are the most representative at European level.

Currently there is neither a unique methodology nor a general accepted agreement on calculating the environmental impact of leather processing (Brugnoli and Král, 2012). Nonetheless most of the LCA studies are conducted partially or sometimes fully in accordance with the ISO standards namely ISO 14044 and ISO 14040 (ISO 14044, 2006; ISO 14040, 2006). In the case of an LCA study conducted for Italian and Spanish bovine leather production it is asserted that LCA methodology was not applied completely in accordance with the requirements of the ISO 14040 (Notarnicola et al., 2007). The ISO 14044:2006 titled "Environmental management-Life cycle assessmentRequirements and guidelines", specifies requirements and provides guidelines for life cycle assessment (LCA), the ISO 14040:2006, titled "Environmental management-Life cycle assessment - Principles and framework" - describes the principles and framework for LCA.

The ILCD International Reference Life Cycle Data System handbook is a useful document that provides detailed guidance for planning, developing, and reporting life cycle emission and resource consumption inventory (LCI) data sets and Life Cycle Assessment studies (ILCD handbook, 2010). Likewise the document "Best Available Techniques (BAT) Reference Document for the Tanning of Hides and Skins" provides valuable insights into leather industry, thus very useful for conducting LCA in the mentioned industry (BAT, 2013).

Moreover conducting an LCA study is a complex task with numerous variables that hardly can be controlled and frequently the result does not have mathematical precision. Leather processing implies the use of a wide variety of chemical substances, some of them not presented in the current software for generating a LCA report. Hence the researchers have four options: 1) to choose from software database a substitute chemical substance that might have a similar environment impact, 2) if the consumption of the substance is lower than a certain percentage, e.g. $0.5 \%$, reported to the quantity of leather, it can be excluded, 3) when possible, to create a custom chemical flow in the LCA database software "mixing" the existing database chemical substances, components of the absent substance to generate the needed substance, 4) to exclude the chemical substance.

Impact categories are scientific definitions that link the specific substances to specific environmental issues:

- Abiotic Depletion (ADP) - unit: MJ, depletion of nonrenewable resources, i.e. fossil fuels, metals and minerals;

- Global Warming Potential (GWP) - unit: $\mathrm{kg} \mathrm{CO}_{2}$-Equiv., the impact of greenhouse gases on global warming;

- Acidification Potential (AP)- unit: kg SO2-Equiv., impact on environment of acid gases released into the air, acid rain

- Photochemical Ozone Creation Potential (POCP) - unit: kg Ethene-Equiv., change in the amount of the ozone formed due to various gas emissions

- Ozone Layer Depletion Potential (ODP) - unit: kg R11-Equiv., is the relative amount of degradation to the ozone layer ;

- Eutrophication Potential (EP) - unit: kg Phosphate-Equiv., Over-fertilization of soils and water. 
ICAMS $2016-6^{\text {th }}$ International Conference on Advanced Materials and Systems

One form of environmental impact assessment, LCA, in leather processing is the Global Warming Potential (GWP 100 years) [ $\mathrm{kg} \mathrm{CO}_{2}$-Equiv.] for manufacturing $1 \mathrm{~m}^{2}$ of finished leather. In the Table 1 is depicted the range of values of $\mathrm{CO}_{2}$ indentified in literature:

Table 1. World Leather Industry $\mathrm{CO}_{2}$, values of $\mathrm{CO}_{2}$ emissions $/ \mathrm{m}^{2}$ of leather

\begin{tabular}{ccccc}
\hline Category & Unit & Total & Performance level & Source \\
\hline $\mathrm{GWP}_{100}$ & $\mathrm{KgCO}_{2}$ & 2.70 & - & Naviglio, 2015 \\
\hline \multicolumn{5}{c}{$\mathrm{CO}_{2}$ Guide for Ambush, $\mathrm{KgCO}_{2}$ of leather produced } \\
\hline & $0-6.58$ & Good & www.liteleather.com \\
& $6.58-8.04$ & Average & ISA Tan Tec \\
& $8.04-9.65$ & Fair & \\
& $9.65-15$ & Low & \\
\hline
\end{tabular}

According to www3.epa.gov (2016), $\mathrm{CO}_{2}$ has a GWP of 1 regardless of the time period used as reference and its concentrations in Earth's atmosphere will last thousands of years.

We mention here some LCA studies for leather industry. A LCA of Italian and Spanish Tanning Systems was conducted by Notarnicola et al. (2011). The scope: manufacturing of chrome tanned leather for women's shoes. The approach was cradleto-gate, functional unit $185.8 \mathrm{~m}^{2}$ of chrome tanned bovine leather equivalent to $200 \mathrm{~kg}$ of leather, thickness $1.3 \mathrm{~mm}$. Methodology adopted: standards ISO 14040, ISO 14044. System boundaries include upstream, core and downstream processes of Spanish and Italian tanning systems. Location of the study: Santa Croce, Italy; Igualada, Spain. A comparative LCA cradle-to-gate study of Romanian tanning system for two different tanning technologies was conducted by researchers from Leather and Footwear Research Institute, Bucharest, Romania (Deselnicu et al., 2014a, 2014b). The authors asserted that the new tanning technology developed within the institute generates $15 \%$ less carbon footprint than classical chrome tanning system.

\section{CASE STUDY}

The case study presented in this section is a part of a product system life cycle assessment, namely a gate-to-gate LCA, evaluating the environmental impact of the core processes of leather processing. The LCA case study was conducted in Romania during 2015-2016, using data from 2014, briefly described in Table 2. Leather processing data were collected from a tannery from Ilfov, Romania. The recipe and all the processing operations for manufacturing finished leather for footwear industry were analysed.

Table 2. Quantity of leather processed, and consumptions recorded for 2014

\begin{tabular}{lcc}
\hline & Quantity & Unit \\
\hline Full grain leather for footwear industry, & 58797 & $\mathrm{~m}^{2}$ \\
bovine leather tanned with chromium salts & & \\
Electric energy & 411272 & $\mathrm{kWh}$ \\
Natural gas & 170776 & $\mathrm{~m}^{3}$ \\
Water (process water) & 13179 & $\mathrm{~m}^{3}$ \\
Diesel oil for movement of vehicles & 2421 & 1 \\
\hline
\end{tabular}


The study was conducted using GaBi ts - Life Cycle Assessment software, Software - System and Database for Life Cycle Engineering, compilation 7.2.2.28, database version $6.115,(\mathrm{GaBi}, 2016)$. Hence the results of the LCA presented in the current section were generated by the mentioned software solution.

The scope of the analysed leather production system is: production of finished leather for footwear industry. The functional unit of LCA is 1 square metre $\left(\mathrm{m}^{2}\right)$ of finished bovine leather, thickness 1.4-1.6 mm, assortment shoe upper leather. As a gateto-gate approach, system boundaries include the following leather processing operations: Desalting, Soaking, Liming, Fleshing - Trimming - forming Beam House phase, Deliming - Degreasing, Bating, Pickling, Tanning, Wringing Pressing, Splitting after Tanning (e.g. Wet Blue Splitting) - forming Tanyard phase, Shaving - Trimming, Clearing, Neutralisation, Retanning, Dyeing - forming Dyeyard phase, Fatliquoring, Sammying - Setting out, Vaccum Drying, Hang Free Drying, Conditioning, Staking, Trimming, Roller Coating - Drying, Spray Coating, Drying, Embossing, Cutting forming finishing phase. The plan from GaBi ts software of the conducted LCA which includes all the processing operations and corresponding phases for leather processing is presented in Figure 1.

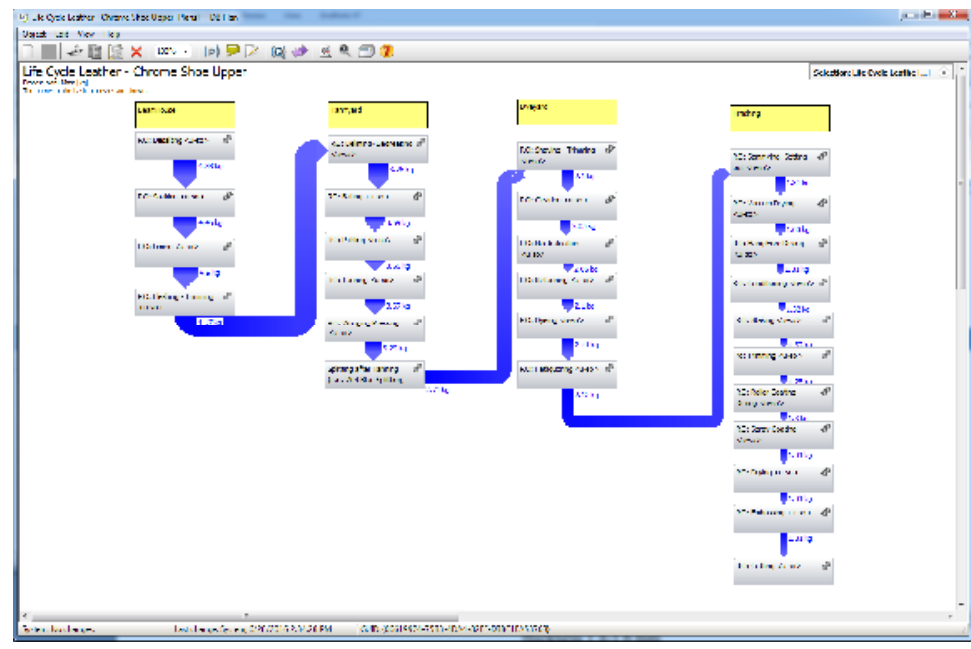

Figure 1. Plan of the LCA from GaBi ts software

Technological reference flows mentioned below are the ones used in LCA case study for manufacturing 1 square metre $\left(\mathrm{m}^{2}\right)$ of finished bovine leather: 1$)$ bovine wet salted hides, bovine pelts, wet blue, crust etc. - equivalent weight in $\mathrm{kg}$; 2) equivalent quantity of natural gas ( $\mathrm{kg}$ ) consumed for water and air heating; 3) electricity in $\mathrm{kWh}$ consumed by tannery machineries; 4) Process water - equivalent in $\mathrm{kg}$; 5) chemical substances - equivalent quantity in $\mathrm{kg} ; 6$ ) waste for recovery in kg resulted from the technological process; 7) waste water in $\mathrm{Kg}$ resulted from leather processing.

Modeling of the LCA for beamhouse operations is depicted in the Figure 2, which shows the aggregated data plan from GaBi ts. Due to space constraints we present only the first main processing phase of leather processing. 
ICAMS $2016-6^{\text {th }}$ International Conference on Advanced Materials and Systems

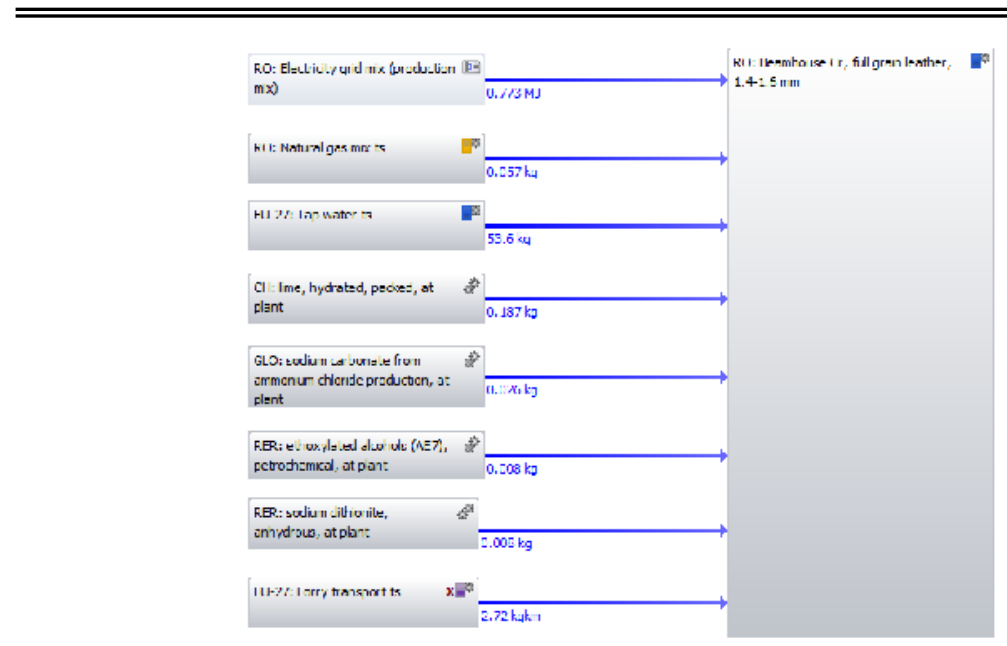

Figure 2. Beamhouse phase, modelled by LCA software GaBi ts

The results of the LCA study regarding the GWP impact category are presented in Table 2. From the data we had it seems that finishing phase generates the highest pollution in terms of $\mathrm{CO}_{2}$, followed by Dyeyard and Beamhouse phase. What stands out is that tanyard phase generates the lowest pollution from all processing phases. This is unusual for LCA studies in general.

Table 2. LCA impact categories for manufacturing natural full grain, bovine leather, thickness $1.4-1.6 \mathrm{~mm}$

\begin{tabular}{lc}
\hline & GWP \\
\hline Beamhouse & 0.426 \\
Tanyard & 0.332 \\
Dyeyard & 0.983 \\
Finishing & 1.623 \\
Total & $\mathbf{3 . 2 8 9}$ \\
Unit & $\mathrm{kg} \mathrm{CO}_{2}$-Equiv. \\
\hline
\end{tabular}

\section{CONCLUSIONS}

Life Cycle Assessment tends to become a common instrument in leather industry. Increasingly more studies are published, values that define the impact on the environment are made public. In this respect the current paper presented a gate-to-gate LCA case study based on data collected from an important tannery from Romania, for production made during one year; full grain leather assortment, bovine leather, chrome tanned. The resulting values of the presented LCA study, more precisely of the GWP in terms of $\mathrm{kg} \mathrm{CO}_{2}$ equivalent fall into the ranges of the ones published worldwide in various studies and publications. 


\section{Acknowledgements}

This work was financially supported by MENCS-UEFISCDI, in the frame of Romanian PN II-Partnerships - Joint Applied Research Projects Program - Contract No. $56 / 2012$.

\section{REFERENCES}

Brugnoli, F. and Král', I. (2012), "Life Cycle Assessment, Carbon Footprint in Leather Processing (Review of methodologies and recommendations for harmonization)", Eighteenth Session of the Leather and Leather Products Industry Panel, Shanghai, China, 01-05 September.

$\mathrm{CO}_{2}$ Guide, available from: http://liteleather.com.

Deselnicu, D.C., Crudu, M., Ioannidis, I., Brugnoli, F. (2014a), "Environmental aspects for leather from a Life- Cycle perspective - Part I - Methodology", Proceedings of The 5th International Conference on Advanced Materials and Systems - ICAMS 2014, 23-25 October 2014, Bucharest.

Deselnicu, D.C., Crudu, M., Ioannidis, I., Brugnoli, F. (2014b), "Environmental Aspects for Leather from a Life-Cycle Perspective. Part II: Impact Assessment", Proceedings of The 5th International Conference on Advanced Materials and Systems - ICAMS 2014, 23-25 October 2014, Bucharest.

$\mathrm{ECO}_{2} \mathrm{~L}$ (2014), Climate Protection and Leather, ILM, 16 January 2014.

European Commission (2013), Best Available Techniques (BAT) Reference Document for the Tanning of Hides and Skins, available from: http://eippcb.jrc.ec.europa.eu/reference/BREF/TAN_ Adopted552013.pdf

$\mathrm{GaBi}$ - the leading Life Cycle Assessment software (2016), available from: http://www.gabisoftware.com/international/solutions/life-cycle-assessment, accessed: July 2016.

ILCD handbook (2010), available from: http://publications.jrc.ec.europa.eu/repository/bitstream/JRC48157/ ilcd_handbook-general_guide_for_lca-detailed_guidance_12march2010_isbn_fin.pdf, accessed: July 2016 .

ISO 14040:2006 (2006), Environmental management - Life cycle assessment - Principles and framework, available from: http://www.iso.org/iso/catalogue_detail?csnumber=37456.

ISO 14044:2006 (2006), Environmental management - Life cycle assessment - Requirements and guidelines, available from: http://www.iso.org/iso/catalogue_detail?csnumber=38498.

Naviglio, B., Calvanese, G. and Caracciolo, D. (2015), "La sostenibilita ambientale del cuoio", Cuoio Pelli Materie Concianti, 91(3/4), Maggio/Agosto, 2015, p92.

Notarnicola, B., Puig, R., Raggi, A., Fullana, P., Tassielli, G., Tarabella, A., Petti, L., De Camillis, C. and Mongelli, I. (2007), "LCA of Italian and Spanish Bovine Leather Production Systems in an Industrial Ecology Perspective", in: Industrial Ecology in the Cattle-to-Leather Supply Chain, Franco Angeli, Milano, Italy.

Notarnicola, B., Puig, R., Raggi, A., Fullana, P., Tassielli, G., Tarabella, A., Petti, L., De Camillis, C. and Rius, A. (2011), "Life cycle assessment of Italian and Spanish bovine leather production systems", Afinidad, LXVIII, 553, Mayo - Junio 2011.

Understanding Global Warming Potentials, available from: https://www3.epa.gov/climatechange/ ghgemissions/gwps.html, accessed: 15 July 2016.

Wikipedia, 2015 United Nations Climate Change Conference, https://en.wikipedia.org/w/index.php? title=2015_United_Nations_Climate_Change_Conference\&printable=yes, accessed: 19 July 2016. 